\title{
Implementasi Metode Mau izhotul Hasanah dalam Mengembangkan Pendidikan Karakter: Suatu Studi Kasus Longitudinal
}

\author{
Nuraly Masum Aprily*, Dadan Setiawan, Elan, Yoga Adi Pratama \\ Universitas Pendidikan Indonesia, Indonesia; Institut Agama Islam Negeri (IAIN) Syekh \\ Nurjati, Indonesia; Universitas Pendidikan Indonesia, Indonesia; SD Negeri Harapan 1 \\ Cimahi, Indonesia. \\ Jl. Dadaha No. 18, Tawang, Kota Tasikmalaya, Jawa Barat, Indonesia.
}

Email: nuralymasumaprily@upi.edu

\begin{abstract}
Character education in the aspect of developing students' knowledge today is still weak because it only focuses on memorizing concepts and truths, so that the right method is needed in the implementation process. The inaccuracy of the method used causes character education to be less effective. The purpose of this research is to describe how the implementation of the Mau'izhotul Hasanah method in character education at the Islamic boarding school. This study used a qualitative approach with a longitudinal case study research method. Data through observation and interviews. Data analysis techniques are performed by means of data reduction, data retrieval, withdrawal and leverage. The results revealed that there methods of mau'izhotul hasanah used in building the character of the students in the moral knowledge aspect, namely: 1) reading the yellow book; 2) The method of mau'izhotul hasanah is done openly, spontaneously, and secretly (personal). The implication of research can be used as best practice in the implementation of character education in other general educational institutions.
\end{abstract}

Keywords: Character Education, Akhlaq, Islamic Boarding School, Mau ìzhotul hasanah

Abstrak: Pendidikan karakter pada aspek pengembangan pengetahuan moral peserta didik dewasa ini dianggap masih lemah karena hanya fokus pada hafalan konsep dan kebenaran saja, sehingga dibutuhkan metode yang tepat dalam proses pelaksanaannya. Ketidaktepatan metode yang digunakan menyebabkan pendidikan karakter akan kurang efektif. Tujuan penelitian ini adalah mendeskripsikan bagaimana pelaksanaan metode mau'izhotul hasanah dalam pendidikan karakter di pesantren. Penelitian ini menggunakan pendekatan kualitatif dengan metode penelitian studi kasus. Data dikumpulkan melalui wawancara dan observasi. Teknik analisis data dilakukan dengan cara reduksi data, penyajian data, penarikan kesimpulan dan verifikasi. Hasil penelitian mengungkap bahwa metode mau'izhatul hasanah yang digunakan dalam membangun karakter santri pada aspek pengetahun moral yaitu: 1) Pengajian kitab kuning; 2) Metode mau izhotul hasanah yang dilakukan baik secara terbuka, spontan, dan rahasia (personal). Implikasi penelitian dapat dijadikan best practice dalam pelaksanaan pendidikan karakter di lembaga pendidikan umum yang lain.

Kata Kunci: Pendidikan Karakter, Akhlaq, Pondok Pesantren, Mau `izhotul hasanah

Jurnal Pendidikan Agama Islam Al-Thariqah Vol. 6, No. 1, Januari - Juni 2021

Received : 02 Mei 2021; Accepted : 10 Juni 2021; Published : 30 Juni 2021

*Corresponding Author : nuralymasumaprily@upi.edu 


\section{PENDAHULUAN}

Kekuatan karakter adalah aspekaspek kepribadian yang secara moral dihargai dan dipandang baik. Baumrind (1998) mengemukakan bahwa agar seseorang mampu berbuat baik maka harus mempunyai sifat yang baik, dan memiliki kompetensi untuk melakukan kebaikan dengan baik. Sekarang ini banyak lembaga pendidikan berfokus untuk membantu peserta didiknya agar memperoleh keterampilan dan kemampuan akademik seperti berpikir kritis. Ini tentu akan membantu peserta didik mencapai tujuan hidup mereka dimasa yang akan datang, dan tentu saja penting. Meskipun demikian, tanpa karakter yang baik, peserta didik mungkin tidak akan memiliki keinginan untuk melakukan hal yang benar.

Dalam mewujudkan hal tersebut, pada tahun 2010 pemerintah Indonesia melalui Kementerian Pendidikan Nasional (Kemendiknas) meluncurkan program pendidikan karakter yang bertujuan untuk meningkatkan kualitas karakter manusia Indonesia ke arah yang lebih baik. Lembaga-lembaga pendidikan dan sekolah memiliki tanggung jawab yang besar dalam mewujudkan harapan tersebut, sehingga sekolah dituntut tidak hanya menekankan pengembangan kognitif melalui hafalan konsep yang merupakan ciri otak kiri, tetapi juga mengembangkan otak kanan dengan menekankan perasaan, cinta kasih, pembiasaan, dan perbuatan yang baik dalam kehidupan keluarga, sekolah dan masyarakat (Pusat Perkembangan Kurikulum, 2009; Sukenti, and Tambak, 2020; Nasional, 2006).

Menurut Lickona (1997) pendidikan karakter mencakup tiga unsur pokok, yaitu mengetahui kebaikan (knowing the good), mencintai kebaikan (desiring the good), dan melakukan kebaikan (doing the good). Maka pendidikan karakter yang baik harus melibatkan bukan saja aspek pengetahuan yang baik (moral knowing), akan tetapi juga merasakan dengan baik (moral feeling), dan akhirnya menjadi perilaku yang baik (moral action).

Namun dalam pelaksanaannya ketiga ranah pendidikan karakter tersebut belum sepenuhnya tersentuh dan dapat dilaksanakan dengan baik, belum efektifnya pembinaan karakter di sekolah saat ini bukan karena tidak adanya nilainilai karakter yang ditawarkan atau ditentukan oleh otoritas publik dalam hal ini sekolah, namun cara dan metode untuk menanamkan dan membangun karakter itu sendiri yang sebenarnya harus terus ditingkatkan.

Sebagai contoh dari pengembangan aspek moral knowing saja yang dirasa masih kurang maksimal, karena terlalu fokus pada aspek kognitif level rendah seperti recall (hafalan) misalnya, dimana guru hanya mewajibkan peserta didik untuk mengetahui, menghafal konsep dan kebenaran tanpa menyentuh perasaan dan hati nurani peserta didik (Hanafi, 2017; Tambak, and Sukenti, 2020). Hal ini tentu berbeda dengan pendapat Lickona (2012) yang menjelaskan bahwa pengembangan aspek moral knowing diindikasikan dengan kesadaran moral peserta didik termasuk memahami mana yang baik dan mana yang tidak baik, pengetahuan nilai, pengetahuan tentang landasan moral, penalaran moral, pengambilan keputusan, dan pengenalan diri. Hal ini berarti pendidik harus mampu mengembangkan kemampuan peserta didik untuk mengetahui berbagai situasi yang akan dihadapi, dilatih untuk memilih hal yang benar untuk dilakukan dan kemudian melakukannya.

Sejalan dengan pendapat Hakam (2015) yang menjelaskan bahwa keyakinan seseorang terhadap nilai, moral dan norma akan direfleksikan dalam cara berpikir, sikap dan tindakan seseorang. Keyakinan seseorang terhadap nilai, kesadaran dan kematangan seseorang dalam moral, serta penghargaan dan ketaatan seseorang terhadap norma adalah hasil pendidikan dan pengalamannya. Sedangkan Cooley (2008) mengungkapkan dalam mendidik karakter 
peserta didik itu membutuhkan strategi dan metode instruktif yang tepat untuk menanamkan nilai-nilai karakter yang baik pada siswa melalui pembelajaran di sekolah, karena ketidaktepatan dari strategi atau metode yang digunakan akan menyebabkan pendidikan karakter menjadi tidak efektif.

Bertemali dengan penjelasan pada paragraf sebelumnya, terdapat beberapa faktor yang berpengaruh terhadap pembentukan karakter seseorang salah satunya adalah pola komunikasi yang baik yang dijalin antara orang tua dan anak dapat berpengaruh terhadap karakter anak. Ini sejalan dengan penelitian yang telah dilakukan oleh Charissa, Cheah, Gürsoy, \& Balkaya-Ince (2021) yang mengemukakan bahwa faktor keharmonisan atau kehangatan hubungan antara orang tua dan anak menjadi faktor penting dalam pembentukan karakter anak. Selain penelitian di atas, penelitian yang berkaitan dengan pendidikan karakter sebenarnya telah banyak dilakukan oleh peneliti sebelumnya diantaranya penelitian yang dilakukan oleh Rokhman et al. (2014) yang meneliti tentang pendidikan karakter untuk Indonesia generasi emas. Selanjutnya penelitian yang dilakukan oleh Birhan et al. (2021) yang meneliti tentang pendidikan karakter dan moral di sekolah dasar. Hasil dari penelitian ini adalah peran guru dan orang tua sangat penting dalam membangun karakter anak. Guru dan orang tua harus menjadi teladan yang baik. Pendidikan karakter juga harus dimasukan dalam setiap pembelajaran dengan berbagai media dan cara. Hal ini terbukti efektif dalam membangun karakter anak.

Hal ini senada dengan penelitian yang dilakukan oleh Harun (2013) yang mengemukakan bahwa peran keluarga dan pendidikan karakter di sekolah berperan penting dalam mengembangkan karakter seseorang. Kemudian penelitian lainnya adalah tentang manfaat pendekatan $3 \mathrm{H}$ untuk pengembangan karakter. Dalam hal ini karakter merupakan hal yang paling penting dalam kehidupan sehingga karakter harus terus dikembangkan baik melalui kegiatan dialog, refleksi kritis, dan dalam pendidikan (Wright \& Emich, 2020).

Berdasarkan beberapa penelitian terdahulu di atas penelitian yang sudah dilakukan masih bersifat secara umum mengenai pentingnya pendidikan karakter bagi anak. Hal yang berbeda dari penelitian sebelumnya adalah dalam penelitian ini peneliti menggali secara lebih mendalam tentang metode mau'izhotul hasanah sebagai salah satu cara dalam mengembangkan karakter. Karakter anak di pondok pesantren tempat penelitian ini terbilang cukup baik. Hal ini terimplikasi dari sikap anak yang penuh dengan sopan santun, jujur, taat kepada guru, dan berpenampilan rapih. Informasi ini diperoleh dari hasil observasi peneliti yang dilakukan secara langsung.

Dalam dunia dakwah Islam dikenal dengan istilah mau izhotul hasanah, yaitu sebagai salah satu metode yang digunakan untuk meningkatkan konsep diri, pengetahuan, penanaman dan pemahaman nilai-nilai kebaikan kepada seseorang ( $\mathrm{mad}^{\prime} u$ ) yang disampaikan oleh seorang guru atau $d a^{\prime} i$ agar terjadi perubahan perilaku seseorang, baik dalam pengetahuan, sikap, dan tindakan ke arah yang lebih baik. Sehubungan dengan hal tersebut, metode mau izhotul hasanah ini dapat dijadikan sebagai solusi untuk mengatasi permasalahan karakter bangsa karena metode ini memiliki dampak yang positif terhadap pengembangan karakter anak.

Menurut Sliwa (2017) moral knowing tidak hanya bertumpu pada kemampuan untuk mengetahui mana yang benar dan salah. Namun siapa orang yang memberikan nasihat tentang moral juga menjadi sangat penting, karena merupakan bagian integral dalam penanaman nilai-nilai moral. Sehingga dibutuhkan orang yang memiliki 
kebijakan dibidang moral yang sangat mendalam untuk menyentuh aspek moral knowing peserta didik.

Najih (2016) dalam penelitiannya mengungkapkan bahwa mau izhotul hasanah adalah sebuah metode berupa nasehat yang disampaikan melalui perkataan untuk mendekatkan manusia kepada Rabb-Nya dengan lemah lembut dan menyentuh jiwa sesuai dengan taraf kemampuan berpikir orang yang menerimanya. Adapun yang dimaksud lemah lembut yaitu nasehat yang diberikan dengan bahasa yang baik maupun santun serta enak didengar. Sedangkan menyentuh jiwa yaitu dengan penuh kasih sayang sehingga mampu masuk ke relung hati terdalam. Dalam metode mau izhotul hasanah ada 4 fungsi meliputi: 1) pelajaran atau pengajaran; 2) fungsi peringatan; 3) fungsi nasehat; dan 4) fungsi larangan.

Sementara itu menurut Mahmuddin et al. (2020) diperoleh hasil bahwa metode mau'izhotul hasanah membawa perubahan terhadap self concept siswa. Metode dakwah mau'izhotul hasanah dalam proses pembelajaran dapat diterapkan kepada siswa untuk lebih memahami nilai-nilai kebaikan yang ada dalam Islam untuk kemudian dipraktekkan dalam kehidupan seharihari. Sedangkan menurut Labibah, et al. (2018) dan Hamzah, Tambak, and Ariyani (2017) melalui metode mau'izhotul hasananah dapat meningkatkan kualitas akhlak anak jalanan. Terciptanya hubungan yang makin baik, antara guru ( $d a^{\prime} i$ ) dan murid (anak jalanan) baik melalui kegiatan ceramah, konsultasi maupun pergaulan biasa bisa mengakibatkan hubungan yang harmonos dan saling membutuhkan satu dengan yang lainnya.

Berdasarkan berbagai pendapat di atas, maka fokus penelitian ini adalah; penggunaan metode mau'izhotul hasanah dalam pengajian kitab kuning oleh guru dalam mengembangkan karakter santri; implementasi metode mau'izhotul hasanah dalam pembinaan karakter santri di pondok pesantren Cipari Kabupaten Garut, Indonesia. Berdasarkan hal ini maka akan ditemukan implementasi metode mau'izhotul hasanah dalam mengembangkan pendidikan karakter santri di pondok pesantren.

\section{KONSEP TEORI}

Lickona (2012) mendefinisikan pendidikan karakter sebagai usaha yang disengaja untuk menumbuhkan kebaikan. sedangkan Howard et al. (2004) mendefinisikan pendidikan karakter sebagai upaya untuk mempersiapkan individu untuk membuat penilaian etis atas setiap tindakannya, yaitu melakukan apa yang orang anggap harus dilakukan. Oleh karena itu, Howard et al. (2004) mencatat bahwa pendidikan karakter secara signifikan mempersiapkan peserta didik untuk membuat keputusan yang baik karena mereka akan menghadapi berbagai masalah dan tantangan dalam hidup. Kemudian menurut Aprily (2019) pendidikan karakter adalah pendidikan yang mengajarkan kebiasaan cara berpikir dan perilaku yang membantu individu untuk hidup dan bekerjasama sebagai anggota keluarga, masyarakat, dan warga negara, serta membantu individu untuk membuat keputusan yang dapat dipertanggungjawabkan.

Selanjutnya karakter baik dalam sudut pandang agama/spiritual dalam hal ini adalah agama Islam, telah termaktub dalam al-Qur'an dan Hadits yang disebut sebagai Akhlakul Karimah (perilaku mulia). Penjelasannya dalam bahasa Arab, bahwa kata akhlak adalah jamak dari kata "khuluq" yang berarti perangai, tabiat, dan sikap yang menetap kuat di dalam diri seseorang dan merupakan sumber dari timbulnya perbuatan-perbuatan tertentu dari dirinya. Hal ini sesuai dengan pendapat seorang ulama besar bernama Ibnu Miskawaih (Hamim, 2017) yang menjelaskan akhlak adalah kemampuan jiwa untuk melahirkan satu perbuatan secara spontan tanpa pemikiran atau pemaksaan. Dilihat dari perspektif Islam, akhlak juga adalah ilmu pengetahuan 
tentang keutamaan-keutamaan dan cara memperolehnya agar jiwa seseorang menjadi bersih dan memiliki pengetahuan tentang kehinaan-kehinaannya jiwa, lalu kemudian bertekad untuk mensucikannya (Tambak, et al. 2020).

Berdasarkan pendapat-pendapat diatas, dapat disimpulkan bahwa pendidikan karakter adalah upaya untuk mengembangkan prilaku yang mencakup kebiasaan yang baik dan keterampilan membuat keputusan yang bertanggung jawab, sehingga menjadi pribadi yang bertanggung jawab dan dewasa. Lickona (1997) menjelaskan bahwa pendidikan karakter mencakup tiga unsur pokok, yaitu mengetahui kebaikan (knowing the good), mencintai kebaikan (desiring the good), dan melakukan kebaikan (doing the good). Maka pendidikan karakter yang baik harus melibatkan bukan saja aspek pengetahuan yang baik (moral knowing), akan tetapi juga merasakan dengan baik (moral feeling), dan akhirnya menjadi perilaku yang baik (moral action).

Apabila digambarkan unsur-unsur dari karakter baik yang menyatu dalam kehidupan seseorang adalah seperti di bawah ini:

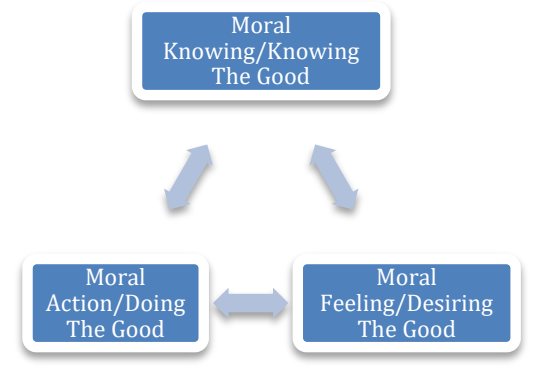

Gambar 1.1. Keterkaitan antar komponen karakter (Lickona, 1997).

Moral knowing diindikasikan dengan kesadaran moral termasuk memahami mana yang baik dan mana yang tidak baik, pengetahuan nilai, pengetahuan tentang landasan moral, penalaran moral, pengambilan keputusan, dan pengenalan diri. Hal ini berarti pendidik harus mampu mengembangkan kemampuan peserta didik untuk mengetahui berbagai situasi yang akan dihadapi, dilatih untuk memilih hal yang benar untuk dilakukan dan kemudian melakukannya Sedangkan moral feeling diindikasikan dengan hati nurani, harga diri, empati, mencintai kebaikan, pengendalian diri, dan rendah hati. Terakhir moral action tampak dalam kompetensi, kemauan, dan kebiasaan untuk melakukan apa yang diketahui dan dirasakan dengan mempertimbangkan segala keadaan dan fakta yang relevan untuk kemudian memiliki kehendak untuk bertindak. Singkatnya karakter yang baik adalah gambaran pribadi yang utuh, memiliki indentitas moral yang jelas (Isnarmi, 2016; Tambak, and Sukenti, 2020).

Dalam sudut pandang Islam pendidikan karakter dikembangkan secara bertahap. Pertama, dalam membentuk karakter dan akhlak peserta didik harus didasarkan pada pengetahuan, yakni untuk mengetahui mana yang benar dan mana yang salah salah agar dapat bertanggung jawab baik sebagai individu (fardhu 'ain) dan sebagai bagian dari masyarakat (fardhu kifayah). Kedua, mengidentifikasi tindakan korektif dan kebenaran yang dirasakan di balik tindakan. Ketiga, identifikasi pengetahuan dan pemahaman tentang tindakan yang dipilih dan mempertahankan pilihan tindakan tersebut ('azm). Akhirnya, tindakan tersebut harus menjadi perwujudan perilaku teladan (Ahmed, 1970; Sukenti, and Tambak, 2019).

Dalam Islam pendidikan karakter lebih familiar dengan istilah pendidikan akhlak, pendidikan akhlak merupakan sesuatu yang sangat fundamental dan dilihat dari fokusnya pendidikan akhlak harus berpedoman dan berlandaskan dengan Al-Qur'an dan praktisnya dengan kepribadian Nabi Muhammad SAW (Haibah et al., 2020).

Ahklak dalam kehidupan manusia menempati suatu hal kedudukan yang penting, sebagai individu maupun masyarakat dan bangsa, sebab jatuh bangunya suatu masyarakat itu 
tergantung kepada akhlaknya. Apabila masyarakat itu akhlaknya baik, maka sejahteralah lahir dan batinya, kemudian apabila akhlak di masyarakat itu rusak maka rusaklah lahir dan batinnya (Hamzah dan Nasrul, 2020; Tambak, Amril, and Sukenti, 2021).

Sedangkan menurut Romdoni dan Malihah (2020) pendidikan karakter tidak hanya mengajarkan sesuatu yang dianggap baik atau salah kepada anak, jauh dari itu pendidikan karakter merupakan sebuah pembiasaan tentang kebaikan sehingga anak memiliki pengetahuan, pemahaman dan kemampuan dalam menjalankan kehidupannya secara baik dan harmonis.

Saputra (2011) menjelaskan makna mau`izhotul hasanah dapat diartikan sebagai sebuah artikulasi yang mengandung komponen bimbingan, pelatihan, pengarahan, cerita, kabar gembira, teguran, pesan-pesan positif (wasiat) yang dapat dijadikan aturan dalam kehidupan agar selamat dunia dan akhirat. Sedangkan menurut Mahmuddin et al. (2020) mau`izhotul hasanah pengetahuan dan nasihat yang hebat, yang membuat seseorang menjauhkan diri dari perbuatan buruk melalui tarhib dan targhib (dorongan dan motivasi) yang dapat menyentuh hati dan memberikan kesan yang mendalam dalam hati sanubari, sehingga memiliki kelembutan hati dan memperbaiki kualitas diri dalam perilakunya sehari-hari.

Mau'izhotul hasanah merupakan kalimat atau ucapan yang diucapkan oleh seorang guru, da'i, orang tua, kyai, ustadz/ustadzah yang disampaikan dengan cara yang baik, lembut, bijak, berisikan petunjuk-petunjuk ke arah kebajikan, diterangkan dengan gaya bahasa sederhana agar yang disampaikan dimengerti, dipahami, dihayati dan pada tahapan selanjutnya dapat diamalkan sehingga individu (mad'u) yang dinasehati memperoleh kebaikan dan menerima dengan rela hati serta merasakan kesungguhan $d a^{\prime} i$ dalam menyelamatkan mereka dari suatu kemadaratan (Najih, 2016).

Metode mau'izhotul hasanah dalam pendidikan karakter adalah untuk mengembangkan aspek moral knowing yang selama ini masih dianggap hanya sebagai proses menghafal konsep-konsep kebaikan saja, melainkan terdapat beberapa langkah penting yang harus dilakukan oleh guru dalam pengembangan aspek moral knowing. Langkah-langkah tersebut menurut Lickona (2012) adalah sebagai berikut:

1) Kesadaran

moral;

Pertama, menggunakan kemampuan berpikir untuk menyadari bahwa satu keadaan menuntut penilaian moral, kemudian berfikir dengan saksama tindakan apa yang benar. Kedua, mengambil pelajaran dari setiap persoalan yang dihadapi.

2) Mengetahui nilai-nilai moral; Pewarisan nilai-nilai dari generasigenerasi sebelumnya. Mengetahui sebuah nilai berarti juga mengerti bagaimana menerapkannya dalam berbagai macam situasi.

3) Melihat melalui berbagai sudut pandang; kemampuan untuk melihat melalui sudut pandang orang lain, melihat satu keadaan seperti yang mereka lihat, membayangkan apa yang mungkin mereka pikirkan, lakukan dan rasakan.

4) Alasan moral, melibatkan pemahaman tentang moral dan alasan mengapa seseorang harus bermoral.

5) Membuat keputusan, mampu memikirkan jalan keluar mengenai berbagai masalah moral, yakni keterampilan untuk merefleksikan pengambilan keputusan.

6) Pengetahuan diri sendiri, menjadi seseorang yang bermoral menuntut kemampuan untuk merekam ulang prilaku dirinya sendiri dan mengevaluasinya dengan kritis. 


\section{METODE PENELITIAN}

Pendekatan yang digunakan dalam penelitian ini adalah pendekatan kualitatif dengan jenis studi kasus. Penelitian kualitatif adalah sebuah tradisi khusus dalam ilmu sosial yang secara fundamental tergantung pada pengamatan manusia baik dalam wawasan maupun dalam terminologi (Moleong, 2009). Penelitian studi kasus merupakan penelitian yang menggali secara mendalam tentang segala sesuatu objek yang diteliti.

Pendekatan kualitatif yang digunakan dalam penelitian ini adalah untuk mengetahui dan mendeskripsikan secara jelas dan rinci tentang metode mau'izhotul hasanah dalam proses pembinaan karakter pada aspek moral knowing santri, oleh karena itu peneliti melakukan serangkaian kegiatan di lapangan mulai dari eksplorasi hingga lokasi penelitian, studi orientasi, dan dilanjutkan dengan studi terfokus di pondok pesantren Cipari Kabupaten Garut.

Dalam penelitian ini sumber data diperoleh dalam bentuk kalimat atau ucapan lisan dari pelaku subjek (informan). Sebagai informan kunci adalah Kyai sebagai pimpinan pesantren (45 tahun), kemudian dilanjutkan dengan sumber data dari 1 orang ustadz (43 tahun) yang sudah mengabdi selama 20 tahun dan 1 orang santri (18 tahun), dengan demikian data yang diperoleh dalam penelitian ini benar dan akurat sesuai dengan fokus penelitian.

Informan dalam penelitian ini adalah sebagai berikut:

\begin{tabular}{|c|c|c|c|}
\hline No & Kode & Nama & Jabatan \\
\hline 1 & PP/IF1 & KH. S & $\begin{array}{l}\text { Pimpinan } \\
\text { Pondok } \\
\text { Pesantren }\end{array}$ \\
\hline 2 & UST/IF2 & MS & $\begin{array}{l}\text { Ustadz (Waka } \\
\text { Kurikulum } \\
\text { Bidang Kitab } \\
\text { Kuning dan } \\
\text { Tahfidz Qur'an }\end{array}$ \\
\hline 3 & SNT/IF3 & SRY & $\begin{array}{c}\text { Santri (Kelas } 3 \\
\text { MAN Cipari) }\end{array}$ \\
\hline
\end{tabular}

Tabel.1 Daftar Informan Penelitian
Pengumpulan data dalam penelitian ini dilakukan dengan 3 (tiga) teknik, yaitu; observasi, wawancara mendalam, dan studi dokumentasi. Teknik observasi digunakan untuk melihat dan mengamati perubahan fenomena fenomena sosial yang tumbuh dan berkembang yang kemudian dapat dilakukan perubahan atas penilaian tersebut bagi pelaksana observasi untuk melihat obyek moment tertentu, sehingga mampu memisahkan antara yang diperlukan dengan yang tidak diperlukan (Margono, 2007). Peneliti melakukan observasi langsung dengan cara peneliti melibatkan diri atau berinteraksi pada kegiatan yang dilakukan oleh subjek dalam lingkungannya, mengumpulkan data secara sistematik dalam bentuk lapangan. Peneliti dalam melakukan observasi lebih cenderung terlibat secara pasif dilakukan dengan melibatkan diri pada kelompok subjek yang sedang melakukan kegiatan. Peneliti ikut serta melakukan kegiatan namun tidak mengajukan pertanyaan sehubungan dengan kegiatan mereka. Akan tetapi hanya melakukan percakapan persahabatan, tetapi tetap sambil memperhatikan kegiatan yang dilakukan para subjek seperti kegiatan pengajian kitab kuning, kegiatan mau izhotul hasanah di masjid, kegiatan muhadhoroh (pidato) santri pada malam Jum'at, dan acara tahunan wisuda akbar tahfidzul Qur'an bil ghoib. Dengan demikian data dikumpulkan tanpa membuat subjek merasa bahwa mereka sedang diobervasi.

Wawancara mendalam (in-depth interview) dalam penelitian ini peneliti menggunakan jenis interview bebas terpimpin, yaitu pelaksanaan interview yang berpedoman pada daftar pertanyaan yang telah di susun dan responden dapat memberikan jawaban secara bebas atau tidak di batasi ruang lingkup jawabannya. Wawancara dilakukan untuk memperoleh konstruksi yang terjadi sekarang tentang orang, kejadian, aktivitas, organisasi, perasaan, motivasi, pengakuan, kerisauan, dan sebagainya. Wawancara dalam hal ini 
adalah percakapan tertentu antara peneliti dengan informan. Percakapan yang dimaksud tidak sekadar menjawab pertanyaan, mengetes hipotesis yang menilai bagaimana istilah percakapan dalam pengertian sehari-hari, melainkan suatu percakapan yang mendalam untuk mendalami pengalaman orang lain dan makna dari orang lain tersebut. Oleh karena itu sebelum dilakukan wawancara, garis-garis besar pertanyaan harus sesuai dengan penggalian data dan kepada siapa wawancara itu dilakukan, harus disiapkan terlebih dahulu. Bentuk pertanyaan tidaklah terstruktur secara tepat guna, tetapi memberikan kemungkinan pertanyaan berkembang dan informasi yang diperoleh sebanyak-banyaknya. Disela-sela percakapan itu, diselipkan pertanyaan pancingan (probing) tujuannya adalah untuk menggali lebih dalam lagi tentang hal-hal yang diperlukan.

Metode interview ini dilakukan langsung dengan pimpinan pondok pesantren Cipari Kabupaten Garut, 1 orang ustadz ,dan 1 orang santri untuk mendapatkan data-data yang dibutuhkan. Data yang di ambil adalah tentang bagaimana metode yang digunakan oleh pesantren Cipari dalam mengembangkan aspek moral knowing santrinya, dan bagaimana pelaksanaan metode mau'izhotul hasanah dalam pendidikan karakter santri di pesantren Cipari.

Analisis data di lakukan dengan mengorganisasikan data, menjabarkanya ke dalam unit-unit, melakukan sintesis, menyusun dalam pola, memilih mana yang penting dan akan di pelajari dan membuat kesimpulan yang akan diceritakan kepada orang lain (Moleong, 2009).

\section{HASIL DAN PEMBAHASAN Pengajian Kitab Kuning}

Berdasarkan hasil wawancara dalam mengembangkan aspek pengetahuan moral para santrinya, pimpinan pondok (IF1) dan ustadz (IF2) menjelaskan pesantren Cipari memberikan pengkajian kitab-kitab kuning yang ditujukan atau berkenaan dengan pendidikan akhlak. Pada tahun pertama para santri akan mempelajari kitab Ta'lim Muta`alim, yang membahas mengenai adab dan etika seorang pelajar ketika menuntut ilmu, selain itu santri pun diajarkan dan dibiasakan akhlak dan adab untuk bersikap ta'dim (menghormati) dan takrim (memuliakan) terhadap guru dan Kyai. Selanjutnya pada tahun kedua santri akan mempelajari kitab Akhlakul Banin untuk santri putra dan kitab Akhlakul banat untuk santri putri, isi dari kitab tersebut yaitu membahas mengenai etika, adab, dan nilai-nilai akhlak yang harus dimiliki seseorang dalam kehidupan sehari-hari. Pimpinan pondok (IF1) melanjutkan manhaj (metode) lain yang dilakukan dalam penyelenggaraan pendidikan akhlak di pesantren Cipari tercermin dari nilai-nilai kebaikan mengenai akhlak, etika dan adab seorang muslim yang disampaikan oleh guru dan Kyai melalui ceramah dan mau`izhotul hasanah (nasihat baik) kepada pada santrinya setiap sebelum memulai pengajian.

Sedangkan menurut seorang ustadz (IF2), tujuan dari pengajian kitab kuning dan pemberian mau izhotul hasanah adalah agar dari segi ilmu santri menjadi tahu mana yang boleh dilakukan mana yang tidak boleh, mana yang baik mana yang salah, namun yang membedakan di pesantren Cipari adalah setiap selesai Kyai dan ustadz memberikan materi tertentu, apa yang disampaikan langsung dipraktekkan dan dicontohkan kepada para santri, karena dalam melakukan sesuatu, santri Cipari tidak akan terlalu banyak bertanya mengenai ilmu dan dalilnya, tapi mereka sangat meyakini apa yang dicontohkan oleh Kyai merupakan suatu kebenaran yang harus diikuti.

Hal tersebut menunjukkan bahwa aspek pengetahuan (moral knowing) merupakan elemen penting dalam pengembangan karakter peserta didik. Disebut elemen penting karena bagaimana seseorang dapat berperilaku 
dan berkepribadian yang baik apabila ia belum mengetahui dan memahami mana yang baik dan mana yang tidak baik (Tambak, et al. 2020). Temuan penelitian tersebut sejalan dengan pendapat Lickona (2009) yang menjelaskan bahwa langkah pertama dalam pelaksanaan pendidikan karakter di lembaga pendidikan adalah mengembangkan aspek pengetahuan (knowing) terlebih dahulu, hal tersebut dilakukan untuk memberikan pemahaman terhadap individu mengenai nilai-nilai kebaikan, mana yang boleh dilakukan dan tidak boleh dilakukan, sehingga peserta didik kelak akan mampu membuat keputusan terbaik dalam menghadapi berbagai permasalahan-permasalahan moral di masa yang akan datang (Hamzah, Sukenti, Tambak, and Tanjung, 2020).

Tujuan utama santri masuk ke pesantren Cipari adalah untuk belajar dan mencari ilmu pengetahuan agama sebanyak-banyaknya. Para santri mendapatkan ilmu dan menambah pengetahuan agama melalui kegiatan pengajian kitab kuning, pembelajaran baca al-Qur'an, dan juga melalui mau izhotul hasanah (nasihat yang baik) yang disampaikan melalui ceramah serta tausiyah Kyai dan para ustadz yang sifatnya umum, maupun nasihat-nasihat baik yang disampaikan kepada santri yang sifatnya lebih pribadi seperti saat konsultasi.

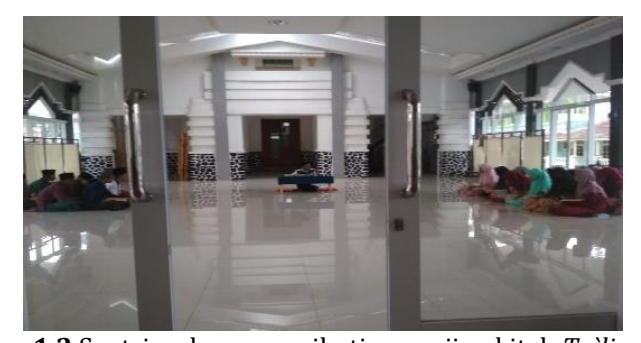

Gambar 1.2 Santri sedang mengikuti pengajian kitab Ta 'lim muta`alim dan mau izhotul hasanah di Mesjid

Berdasarkan hasil pengamatan yang dilakukan oleh peneliti terungkap bahwa pengajian kitab kuning di pesantren Cipari dilaksanakan 2 kali dalam sehari, setelah $b a^{\prime} d a$ Ashar dan setelah ba'da Isya sesuai dengan jadwal kegiatan harian di pesantren Cipari yang wajib diikuti oleh seluruh santri. Berdasarkan hasil pengamatan yang dilakukan peneliti, pengajian kitab kuning setelah ba`da Ashar adalah pengajian kitab Ta'lim Muta 'alim yang diikuti oleh seluruh santri baik putra dan putri, di mana ustadz yang mengajar berada di depan para santri. Para santri menulis dan menerjemahkan kajian yang sedang dibahas oleh ustadz, setelah selesai membacakan kajian yang dibahas, ustadz lalu menerangkan makna dan isi dari kajian tersebut, saat peneliti melakukan observasi kajian yang sedang dibahas adalah mengenai ilmu yang bermanfaat akan didapatkan santri apabila santri bersikap memuliakan dan menghormati guru dan Kyai, para santri mendengarkan dengan seksama penjelasan tersebut dengan suasana yang tenang dan khidmat. Pada akhir pembahasan, ustadz memberikan contoh bagaimana cara mencium tangan guru dan Kyai yang benar, menundukkan pandangan apabila bertemu dengan guru dan Kyai, serta sikap dan cara berbicara yang baik dan sopan ketika sedang berkomunikasi dengan guru dan Kyai

Pengajian kitab-kitab kuning yang ditujukan untuk mendidik karakter di pesantren Cipari seperti kitab Ta lim muta 'alim, kitab Akhlakul Banin, dan kitab Nurul yaqin merupakan sarana pengajaran (transfer of knowledge) kepada para santri untuk mengetahui berbagai konsep akhlak dalam Islam, nilai-nilai kebaikan, adab dan akhlak sebagai seorang santri saat sedang menuntut ilmu dan adab sehari-hari, agar para santri mengetahui dan memahami bagaimana menjadi manusia yang berakhlak baik (akhlakul karimah).

Nasir (2010) menjelaskan bahwa pembelajaran dan pengkajian kitab kuning merupakan ciri khas pembelajaran di pesantren Salafiyah (tradisional). Kitab kuning tidak hanya menjadi pusat orientasi dan pembelajaran, tetapi telah mendominasi studi keislaman pesantren dan mewarnai praktek keagamaan dalam berbagai dimensi kehidupan umat Islam, karena lengketnya dengan kitab kuning, 
kalangan pesantren mencoba bersikap, memaknai dan menjawab hampir seluruh persoalan yang muncul dan berkembang di masyarakat.

Ada dua alasan penting yang mendasari mengapa pesantren memposisikan kitab kuning sebagai referensi dan sumber pengajaran bagi para santrinya, sebagaimana yang diungkapkan oleh Siradj (1999) yaitu di antaranya:

1) Kebenaran kitab kuning bagi kalangan pesantren merupakan referensi yang kandungannya sudah tidak perlu dipertanyakan lagi. Kenyataan bahwa kitab kuning yang ditulis sejak lama dan terus dipakai dari masa ke masa menunjukkan bahwa kitab kuning sudah teruji kebenarannya dalam sejarah yang panjang. Kitab kuning dipandang sebagai pemasok teori dan ajaran yang bersandar pada al-Quran dan Hadits Nabi.

2) Bahwa kitab kuning penting bagi pesantren untuk memfasilitasi proses pemahaman keagamaan yang mendalam sehingga mampu merumuskan penjelasan yang segar tetapi tidak ahistoris mengenai ajaran Islam, al-Quran, dan Hadtis Nabi.

Sedangkan menurut Abdullah (2011) dalam dunia pesantren, posisi kitab kuning sangat strategis karena kitab kuning dijadikan sebagai text book, references, dan kurikulum dalam sistem pendidikan pesantren. Selain sebagai pedoman bagi tata cara keberagamaan, kitab kuning difungsikan juga oleh kalangan pesantren sebagai referensi universal dalam menyikapi segala tantangan kehidupan, oleh karena itu pengajian kitab kuning merupakan tradisi akademik di pesantren yang menjadi bahan dan sumber pelajaran bagi para santrinya. Hal tersebut sejalan dengan temuan penelitian bahwa pesantren Cipari yang merupakan pesantren Salafiyah (tradisional) masih menjaga budaya dan warisan sistem pengajaran dari para pendirinya yaitu salah satunya adalah memberikan pengajaran kitab kuning kepada para santrinya.

\section{Metode Mau izhotul Hasanah \\ Pemberian Mau izhotul Hasanah secara Terbuka}

Selain menggunakan metode

pengajaran kitab kuning, metode selanjutnya dalam rangka mengembangkan aspek pengetahuan moral (moral knowing) dalam pembinaan karakter santri di pesantren Cipari adalah dengan menggunakan metode ceramah dan mau'izhotul hasanah (pemberian nasihat baik).

Dalam sebuah wawancara, seorang santri (IF3) mengungkapkan bahwa dalam mengembangkan aspek pengetahuan para santri mengenai nilai-nilai akhlak yang baik biasanya dilakukan melalui metode ceramah dan mau'izhotul hasanah (pemberian nasihat baik) oleh para ustadz atau Kyai, kegiatan tersebut dilaksanakan sebelum kegiatan pengajian dimulai, setiap selesai melaksanakan sholat Subuh dan sholat Isya berjamaah. IF4 mengaku bahwa mereka mendapatkan ilmu dan pengetahuan yang berharga mengenai mana yang baik mana yang salah, mana yang boleh dilakukan mana yang tidak boleh dilakukan, serta bagaimana menjadi seorang santri (Muslim/Muslimah) yang baik melalui pengajian kitab kuning dan mau izhotul hasanah tersebut.

Sliwa (2017) menjelaskan moral knowing tidak hanya bertumpu pada kemampuan untuk mengetahui mana yang benar dan salah. Namun siapa orang yang memberikan nasihat tentang moral juga menjadi sangat penting, karena merupakan bagian integral dalam penanaman nilai-nilai moral. Sehingga dibutuhkan orang yang memiliki kebijakan dibidang moral yang sangat mendalam untuk menyentuh aspek moral knowing peserta didik. Pesantren memiliki sosok yang memiliki kebijakan dalam hal moral tersebut yaitu Kyai dan para ustadznya yang sangat begitu dihormati dan dijadikan teladan bagi para santrinya. 
Metode mau izhotul hasanah tersebut merupakan salah satu metode yang digunakan oleh Kyai di pesantren Cipari untuk menanamkan nilai-nilai kebaikan kepada para santri untuk kemudian mempraktekkan dan mengamalkannya secara bersama-sama. Sebagaimana hasil wawancara Bersama pimpinan pondok (IF1) dan ustadz (IF2) bahwa dengan metode mau'izhotul hasanah ini, pesantren Cipari ingin ilmu yang dimiliki para santrinya tidak hanya bil kutub (terpaku dengan buku/tulisan), tapi ilmu itu harus menetap bil aqli (hafal dan paham) dan bil qolbi (menetap dalam hati).

Sedangkan menurut santri (IF3) melalui metode mau'izhotul hasanah tersebut, santri tidak hanya sekedar tahu dan hafal saja tentang nilai-nilai akhlak, namun para santri mempraktekkan dan mengamalkan nilai-nilai kebaikan yang sudah diajarkan dalam kehidupan seharihari, cukup dengan mendengarkan perintah, anjuran, dan contoh dari Kyai dan ustadz para santri akan langsung melaksanakannya tanpa perlu tahu dan bertanya dulu teori dan dalilnya apa.

Menurut Nafisah et al. (2018) ada dua ciri nasehat yang digolongkan mau izhotul hasanah: Pertama, menggunakan ungkapan yang diarahkan ke pikiran. Hal ini terlihat dari ungkapan yang digunakan oleh beberapa muffasir, seperti an Nisaburi, al-Baidhawi, dan alAlusi, yaitu kata dalâ'il (bukti), muqaddimah (premis), dan khithâb (seruan). Semua ini jelas terkait dengan fungsi pikiran untuk memahami. Kedua, menggunakan ekspresi yang diarahkan ke hati/perasaan. Hal ini terbukti dari banyaknya muffasir yang mengaitkan dalil tersebut dengan aspek kepuasan atau keyakinan. An-Nisaburi, misalnya, menggunakan kata dalâ'il iqnâ'iyyah (dalil yang memberi kepuasan). Al-Baidhawi dan al-Alusi menggunakan ekspresi alkhithâbât al-muqni'ah (ekspresi memuaskan). Kehadiran kepuasan dan keyakinan (iqnâ) jelas tidak akan konkrit tanpa adanya proses pembenaran dan keyakinan di dalam hati. Semua ini jelas berkaitan dengan fungsi hati untuk percaya atau puas dengan proposisi tertentu. Beberapa upaya untuk menyentuh hati adalah dengan menyampaikan targhîb dan tarhîb, seperti yang ditunjukkan oleh Al-Khazin (AlMunawar, 2003).

Hal tersebut sesuai dengan pendapat Gunawan (2014) yang mengartikan mau`izhotul hasanah adalah nasehat berupa peringatan atau kebaikan dan kebenaran dengan jalan apa yang dapat menyentuh hati dan membangkitkannya untuk beramal. Sedangkan menurut Hamid (1989) mau`izhotul hasanah merupakan salah satu manhaj (metode) dalam dakwah untuk mengajak ke jalan Allah dengan jalan memberi nasihat atau bimbingan dengan lemah lembut agar yang mendengarkan mau berbuat kebaikan. Sedangkan mau izhotul hasanah menurut Mahmudah (2008) dapat diklasifikasikan dalam beberapa bentuk sebagai berikut:

1) Nasihat atau petuah

2) Bimbingan dan pengajaran (pendidikan)

3) Kisah-kisah Nabi, sahabat, dan orang sholeh dalam al-Qur'an

4) Kabar gembira dan peringatan (alBasyir dan al-Nadzir)

5) Wasiat (pesan-pesan positif)

Gunawan (2014) menjelaskan terdapat 3 (tiga) unsur penting dalam metode ceramah dan mau izhotul hasanah yang disampaikan Kyai dan para ustadz di pesantren, yaitu sebagai berikut:

1) Uraian tentang kebaikan dan kebenaran yang harus dilakukan oleh santri misalnya, tentang sopan santun, harus sholat berjamaah di masjid, dan semangat dalam menjalankan ibadah lainnya.

2) Motivasi dalam melakukan amal kebaikan sehari-hari.

3) Peringatan tentang dosa atau akibat yang akan didapat baik oleh diri santri sendiri maupun orang lain apabila 
santri berbuat sesuatu yang dilarang oleh Allah SWT.

\section{Pemberian Mau izhotul Hasanah Secara Tertutup/Personal}

Teknik pemberian nasihat tidak hanya diselenggarakan secara terbuka, spontanitas, atau dalam bentuk ceramah dari Kyai dan para ustadz saja yang dilaksanakan pada forum-forum pengajian bersama santri. Namun berdasarkan hasil observasi yang dilakukan terungkap bahwa pelaksanaan metode mau'izhotul hasanah juga dilakukan secara personal/individu yang dilakukan oleh ustadz-ustadz dan para santri.

Berdasarkan hasil wawancara dengan seorang santri (IF3), dia menguraikan bahwa para santri dapat melakukan konsultasi dengan para ustadz secara mandiri, atau ustadz yang memanggil santri untuk melakukan kegiatan semacam konseling, dimana ustadz lebih banyak menggunakan lisannya untuk mengajukan berbagai pertanyaan-pertanyaan yang menyangkut kehidupan dan kepribadian santri yang harus dijawab santri dengan jujur. Pada momen seperti itu menurut seorang santri (IF3), ia merasa lebih dekat dengan guru atau ustadznya, lebih termotivasi, santri merasa memiliki tempat untuk berkeluh kesah dan meminta saran dari gurunya atas permasalahan-permasalahan yang dihadapi, dan melihat secara langsung keteladan gurunya dalam bertutur kata dan bersikap.

Hal tersebut sesuai dengan pendapat Adz-Dzaky (2004) yang mengungkapkan bahwa agar seorang pendidik bisa mendapatkan jawaban-jawaban yang jujur dan terbuka dari peserta didik saat sedang melakukan konsultasi, maka kalimatkalimat yang terlontar dari seorang pendidik harus berupa kalimat yang mudah dipahami, sopan, dan tidak menyinggung atau melukai hati dari peserta didiknya. Demikan pula saat memberikan mau'izhotul hasanah harus dilakukan dengan kalimat yang indah, bersahabat, menenangkan dan menyenangkan. Arsam (2012) menjelaskan bahwa esensi dari metode mau izhotul hasanah dalam pengembangan karakter seseorang adalah dengan menyentuh aspek hati peserta didik dengan kata-kata yang penuh kelembutan, memberikan nasihat tanpa harus membeberkan dan atau membongkar kesalahan orang lain, sehingga dapat meluluhkan hati yang keras dan lebih mudah melahirkan kebaikan daripada menasehati dengan ancaman dan hukuman.

Sedangkan menurut Gunarsa (1992) metode mau'izhotul hasanah yang dilakukan secara individual/personal bertujuan untuk membantu seseorang agar mampu mengambil satu keputusan dengan memberikan pilihan-pilihan mana yang baik dan mana yang tidak baik, serta untuk menjaga kehormatan seseorang dan masalahnya yang perlu dijaga kerahasiaannya. Menurut Junaidi (2020) pendekatan mau izhotul hasanah adalah suatu proses untuk mengajak dan memotivasi seseorang secara persuasif untuk membuktikan apa yang disampaikan dengan maksud tertentu yang dibarengi dengan rasa tanggung jawab. Sa'diyah (2018) mengungkapkan bahwa mau'izhotul hasanah merupakan suatu kegiatan untuk memberikan motivasi kepada seseorang, dengan memperlihatkan mana yang baik dan mana yang salah, mana yang menguntungkan dan mana yang merugikan, sehingga mampu mengambil keputusan dan bersikap sesuai dengan kaidah-kaidah agama Islam.

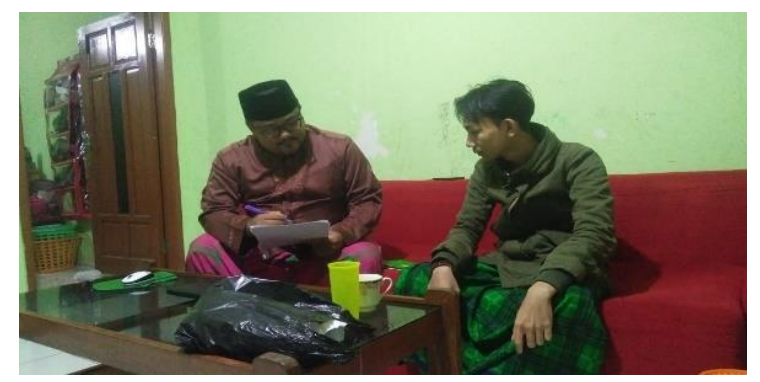

Gambar 1.3 Santri sedang mendapatkan bimbingan dan nasehat secara personal dari Ustadz. 
Marzuki (2015) berpendapat bahwa para guru dan orang tua harus selalu memberikan nasihat-nasihat, teladan, dan perhatian khusus kepada para siswa atau anak mereka dalam rangka pembinaan karakter. Cara ini sangat membantu dalam memotivasi siswa untuk memiliki komitmen dengan aturan-aturan atau nilai-nilai akhlak mulia yang harus diterapkan (Tambak, Ahmad, and Sukenti, 2020). Begitupun halnya Kyai dan para ustadz di pesantren Cipari memiliki peran selain sebagai guru, juga sebagai orang tua para santri karena mereka hidup bersama selama 24 jam di lingkungan pesantren Cipari.

$\begin{array}{ccr}\text { Metode } & \text { mau'izhotul hasanah } \\ \text { merupakan } & \text { penggabungan antara }\end{array}$
kelembutan ucapan dan keteladanan dari seorang pendidik, hal tersebut juga sesuai dengan tuntunan dari Rasululloh SAW sehingga dakwah beliau mampu menarik hati dan simpati dari mad'u-nya (Farihah dan Ismanto, 2018; Ahmad, Tambak, and Syafitri, 2016). Sementara itu menurut Sutrisno (2017) dan Tambak (2014) metode ceramah dan mau izhotul hasanah di pondok pesantren di berikan oleh Kyai dan para ustadz secara terbuka, spontan maupun rahasia. Secara terbuka pemberian nasihat diberikan kepada santri dalam forum yang luas seperti setelah sholat berjamaah, dalam kegiatan pengajian, maupun dalam upacara atau momen hari besar Islam. Sedangkan pemberian nasihat secara tertutup atau rahasia apabila santri mempunyai masalah dan memerlukan solusi dari permasalahannya secara personal. Metode pemberian nasihat ini sering dilakukan oleh ustadz ialah dengan cara spontan, yaitu tidak ditentukan waktu dan tempatnya apabila terdapat kesempatan maka akan diberikan nasihat kepada santri.

Metode ceramah dan mau izhotul hasanah merupakan sesuatu yang sangat penting, sehingga Nabi Muhammad SAW sangat memfokuskan terhadap pentingnya metode nasihat dan bimbingan ini dalam proses pendidikan para sahabatnya. Maka Rasulullah SAW mewajibkan memberi nasihat yang baik dan benar kepada setiap umat Islam. Dengan demikian tentunya umat Islam harus melakukan nasihat sesuai dengan tuntunan al-Qur'an dan sunah Rasul-Nya (Gunawan, 2014; Ahmad, Tambak, and Hasanah, 2018; Ahmad, and Tambak, 2018).

Hal tersebut sesuai dengan temuan penelitian bahwa metode ceramah dan mau izhotul hasanah yang dilaksanakan di pesantren merupakan salah satu cara yang efektif dalam menanamkan nilai-nilai akhlak kepada santri untuk menyentuh aspek pengetahuan (kognitif) santri. mau izhotul hasanah yang diberikan oleh Kyai dan para ustadz biasanya dilakukan setelah selesai sholat berjamaah, atau sebagai pembuka sebelum melaksanakan pengajian rutin. Para santri akan dengan seksama mendengarkan pesan-pesan yang disampaikan oleh Kyai dan para ustadz, karena dilandasi oleh keyakinan terhadap keilmuan, penghormatan, dan kecintaan para santri bahwa apa yang disampaikan oleh Kyai dan ustadz merupakan sesuatu yang berguna dan bermanfaat bagi kehidupan para santri.

\section{PENUTUP}

Dalam mendidik dan membina karakter para santrinya dari aspek pengetahuan moral (moral knowing), pesantren Cipari menerapkannya dengan 2 (dua) cara, yaitu melalui pengajian kitab kuning dan metode mau izhotul hasanah. Pertama, melalui pengajian kitab kuning santri mendapatkan konsep, wawasan, dan pengetahuan yang kuat mengenai nilai-nilai moral dan akhlak dalam Islam. Namun tidak hanya sekedar mengajarkannya, setiap selesai pengajian ustadz akan langsung memberikan contoh dalam mengamalkan pengetahuan tersebut. Dengan begitu selain santri belajar, juga secara tidak langsung sedang ditanamkan nilai-nilai kebaikan di dalamnya, harapannya nilai-nilai tersebut 
tidak hanya muncul dalam kegiatan belajar saja tapi juga menjadi watak kepribadian santri dalam kehidupan sehari-hari. Kedua, metode mau izhotul hasanah digunakan oleh Pesantren Cipari sebagai salah satu manhaj (metode) dalam mengembangkan aspek pengetahuan (moral knowing) santri. Metode tersebut tidak hanya mengedepankan hafalan santri tentang konsep dan nilai-nilai kebaikan dalam Islam saja, tetapi juga menyentuh aspek hati Nurani santri karena dilakukan dengan bahasa yang lemah lembut, personal, dan juga dilakukan secara berulang-ulang dalam setiap kegiatan. Namun metode mau'izhotul hasanah juga diperkuat oleh pesantren dengan mengembangkan aspek moral feeling dan moral action santri melalui berbagai program latihan, pembiasaan, dan pengamalan nilai-nilai akhlak santri dalam kehidupan sehari-hari dimana keteladanan dari Kyai dan Ustadz selalu mewarnai setiap proses pendidikan akhlak di pesantren Cipari.

Dari tahapan-tahapan proses pendidikan akhlak yang diselenggarakan di Pesantren Cipari tersebut bukan merupakan bagian yang terpisah-pisah, melainkan saling berhubungan dan mendukung satu sama lain, tahapantahapan tersebut harus berjalan secara simultan dan istiqomah. Sehingga tujuan dan harapan pesantren dalam membina dan mendidik para santrinya tercapai, yaitu agar santri-santri pesantren Cipari menjadi santri yang memiliki akhlak mulia (akhlakul karimah) baik saat sedang menempuh pendidikan di pesantren maupun nanti setelah santri kembali ke lingkungan masyarakatnya. Hasil penelitian ini dapat dijadikan sebagai best practice bagi lembaga pendidikan umum lainnya dalam pelaksanaan pendidikan karakter, khususnya untuk mengembangkan aspek pengetahuan moral (moral knowing) peserta didik.

\section{DAFTAR RUJUKAN}

Abdullah, Aly. Pendidikan Islam Multikultural Di Pesantren. Yogyakarta: Pustaka Pelajar, 2011.

Adz-Dzaky, Hamdani Bakran. Konseling Dan Psikoterapi Islam. Yogyakarta: AlManar, 2004.

Ahmad, Muhammad Yusuf, Syahraini Tambak, and Uswatun Hasanah. "Pengaruh Kecerdasan Emosional terhadap Penyesuaian Diri Mahasiswa Thailand." Al-Hikmah: Jurnal Agama dan Ilmu Pengetahuan 15.2 (2018): 16-30.

Ahmad, Muhammad Yusuf, Syahraini Tambak, and Mira Syafitri. "Etika Pergaulan Islami Santri Madrasah Aliyah (MA) di Pesantren Jabal Nur Kecamatan Kandis Kabupaten Siak." Al-Hikmah: Jurnal Agama dan Ilmu Pengetahuan 13.2 (2016): 206226.

Ahmad, Mawardi, and Syahraini Tambak. "Penerapan Metode Diskusi Dalam Meningkatkan Hasil Belajar Murid Pada Pelajaran Fiqh." Al-Hikmah: Jurnal Agama Dan Ilmu Pengetahuan 15.1 (2018): 64-84.

Ahmed, K. Some Aspects of Character Building. 1970, http://www.salaam.co.uk/knowledge /aspects.php.

Al-Munawar, Said Agil Husain, Syahraini Tambak, and Umi Kalsum. Aktualisasi nilai-nilai Qu'rani dalam sistem pendidikan Islam. Ciputat Press, 2003.

Aprily, Nuraly Masum. “Nidzomul Ma'had Dalam Pendidikan Akhlak Di Pesantren Cipari Kabupaten Garut." Premiere Educandum: Jurnal Pendidikan Dasar Dan Pembelajaran 9.2 (2019): 141-159.

Arsam, Arsam. "Peran Orang Tua Dalam Membangun Kepribadian Anak." KOMUNIKA: Jurnal Dakwah Dan Komunikasi, 6.1 (2012): 1-15.

Baumrind, D. "Reflections on Character and Competence." The University of Chicago Press 1.1 (1998): 1-28.

Birhan, Wohabie., Shiferaw, Gebeyehu., et. al. "Exploring the Context of Teaching 
Character Education to Children in Preprimary and Primary Schools." Social Science and Humanity Open 4 (2021): 1-6.

Charissa, Gursoy, \& Balkaya-Ince. "Parenting and Social Identity Contributors to Character Development in Muslim American Adolescents." International Journal of Intelectual Relations 81 (2021): 6878.

Cooley, Aaron. "Legislating Character: Moral Education in North Carolina's Public Schools." Educational Studies 43.3 (2008): 188-205.

Fahmy, Rahmi., Bachtiar, Nasri., Rahim, Rida., Malik, Melini. "Measuring Student Perceptions to Personal Character Building in Education: An Indonesian Case in Implementing New Curriculum in High School." Social and Behavioral Science 211 (2015): 851-858.

Farihah, Irzum, and Ismanto Ismanto. "Dakwah Kiai Pesisiran: Aktivitas Dakwah Para Kiai Di Kabupaten Lamongan." Ilmu Dakwah: Academic Journal for Homiletic Studies 12.1 (2018): 46-60.

Gunarsa, Singgih. Konseling Dan Psikoterapi. Jakart: BPK Gunung Mulia, 1992.

Gunawan, Heri. Pendidikan Karakter Konsep Dan Implikasi. Bandung: Alfabeta, 2014.

Haibah, Mujahidatul, et al. "Pembiasaan Membentuk Karaktek Peserta Didik Madrasah Miftahul Huda Musi Rawas Utara." Jurnal Pendidikan Agama Islam Al-Thariqah 5.2 (2020): 24-32.

Hakam, Kama Abdul. Pendidikan Karakter Di Sekolah Dasar. Bandung: UPI Press, 2015.

Hamid, Abdul al-Bilali. Fiqh Al-Dakwah Fii Ingkar Al-Mungkar. Kuwait: Dar alDakwah, 1989.

Hamim, Nur. "Pendidikan Akhlak: Komparasi Konsep Pendidikan Ibnu Miskawaih Dan Al-Ghazali." Ulumuna 18.1 (2017): 21-40.
Hamzah, Hamzah, and Nasrul Nasrul. "Kontribusi Tarekat Naqsabandiyah Dalam Membangun Pendidikan Akhlak Mulia." Jurnal Pendidikan Agama Islam Al-Thariqah 5.2 (2020): 118-128.

Hamzah, Desi Sukenti, Syahraini Tambak, and Wisudatul Ummi Tanjung. "Overcoming self-confidence of Islamic religious education students: The influence of personal learning model." Journal of Education and Learning (EduLearn) 14.4 (2020): 582-589.

Hamzah, Hamzah, Syahraini Tambak, and Nella Ariyani. "Upaya Guru Pendidikan Agama Islam dalam Pembentukan Kepribadian Islam Siswa di SMA Negeri 2 Kelayang Kabupaten Indragiri Hulu." AlHikmah: Jurnal Agama dan Ilmu Pengetahuan 14.1 (2017): 76-95.

Hanafi, Muhammad. "Membangun Profesionalisme Guru Dalam Bingkai Pendidikan Karakter." Jurnal Ilmu Budaya 5.1 (2017): 35-45.

Howard, Robert W., et al. "Politics of Character Education." Educational Policy 18.1 (2004): 188-215.

Isnarmi, Moeis. "Pendekatan KritisTransformatif Dalam PKn: Sebuah Upaya Pengembangan Karakter (Good Character)." Jurnal Social Science 1.1 (2016): 364-378.

Junaidi. "Pendekatan Komunikasi Islam Pada Nilai Mauizah Hasanah." Peurawi 3.1 (2020): 57-69.

Labibah, Roihanah, et al. "Penerapan Metode Mau'izhah Hasanah Dalam Meningkatkan Akhlak Anak Jalanan." Tabligh: Jurnal Komunikasi Dan Penyiaran Islam 3.3 (2020): 39-55.

Lickona, Thomas. "A Comprehensive Approach to Character Building in Catholic Schools." Journal of Catholic Education 1.2 (1997): 159-175.

Mahmudah, Dedeh. Efektifitas Metode Dakwah Mauidzhotul Hasanah Dalam Pembinaan Akhlak Santri At-Taqwa Putra Bekasi. Skripsi, UIN Jakarta, 
2008.

Mahmuddin, Mahmuddin, et al. "Metode Dakwah Mauidzah Al-Hasanah Untuk Meningkatkan Konsep Diri Siswa MTsN Model Palopo." Irsyad: Jurnal Bimbingan, Penyuluhan, Konseling, Dan Psikoterapi Islam 8.3 (2020): 285-300.

Margono. Metodologi Penelitian Pendidikan. Jakarta: Rineka Cipta, 2007.

Marzuki. Pendidikan Karakter Islam. Yogyakarta: Amzah, 2015.

Moleong, Lexy J. Metodologi Penelitian Kualitatif. Bandung: PT Remaja Rosdakarya, 2009.

Nafisah, Neneng, et al. Concept of Mau'izhoh Hasanah and Its Implications in Islamic Education. 25.3 (2019): 532-537.

Najih, Shihabuddin. “Mau'Idzah Hasanah Dalam Al-Qur'an Dan Implementasinya Dalam Bimbingan Konseling Islam." Ilmu Dakwah 36.1 (2016): 144-169.

Nasional, Departemen Pendidikan. "Teropong Pendidikan Kita." Jakarta: Pusat Informasi dan Humas Departemen Pendidikan Nasional (2006).

Nasir, Ridwan. Mencari Tipologi Format Pendidikan Ideal, Pondok Pesantren Di Tengah Arus Perubahan. Yogyakarta: Pustaka Pelajar, 2005.

Nurul Romdoni, Lisda, and Elly Malihah. "Membangun Pendidikan Karakter Santri Melalui Panca Jiwa Pondok Pesantren." Jurnal Pendidikan Agama Islam Al-Thariqah 5.2 (2020): 14-22.

Pusat Perkembangan Kurikulum. Kebijakan Nasional Pendidikan Karakter Bangsa. Jakart: Puskur Litbang Kemendiknas, 2009.

Rokhman., M. Hum., Syaifuddin, Ahmad., Yuliati. "Character Education for Goldern Generation 2045 (National Character Building for Indonesian Golden Years)." Procedia: Social and Behavioral Sciences 141 (2014): 1161-1165.

Sa'diyah, Halimatus. "Internalization of
Islamic Character Education To Students In Elementary School (Sd) Plus Nurul Hikmah Pamekasan Madura." International Journal on Islamic Educational Research (SKIJIER) 2.1 (2018): 134-145.

Saputra, Wahidin. Pengantar Ilmu Dakwah. Jakarta: Rajawali Press, 2011.

Siradj, Said Aqiel. Pesantren Masa Depan: Wacana Pemberdayaan Dan Transformasi Pesantren. Bandung: Pustaka Hidayah, 1999.

Sliwa, Paulina. "Moral Understanding as Knowing Right from Wrong." Ethics 123.1 (2017):521-552.

Sutrisno. "Implementasi Pendidikan Karakter Di Pondok Pesantren Modern Muhammadiyah Boarding School (Mbs) Yogyakarta." Jurnal Elektronik Mahasiswa Pend. Luar Sekolah - S1 6.5 (2017): 509-525.

Sukenti, Desi, and Syahraini Tambak. "Developing Indonesian Language Learning Assessments: Strengthening the Personal Competence and Islamic Psychosocial of Teachers." International Journal of Evaluation and Research in Education 9.4 (2020): 1079-1087.

Sukenti, Desi, and Syahraini Tambak. "Strengthening Islamic Psychosocial and Self-confidence in Develophing Student Thinking Creative." ICOSEEH 20194 (2019): 446-453.

Tambak, Syahraini. "Metode Ceramah: Konsep dan Aplikasi dalam Pembelajaran Pendidikan Agama Islam." Jurnal Tarbiyah 21.2 (2014).

Tambak, Syahraini, and Desi Sukenti. "Strengthening Islamic behavior and Islamic psychosocial in developing professional madrasah teachers." Cakrawala Pendidikan: Jurnal Ilmiah Pendidikan 39.1 (2020): 65-78.

Tambak, Syahraini, and Desi Sukenti. "Pengembangan profesionalisme guru madrasah dengan penguatan konsep khalifah." Hayula: Indonesian Journal of Multidisciplinary Islamic 
Studies 4.1 (2020): 41-66.

Tambak, Syahraini, Mawardi Ahmad, Desi Sukenti, and Abd Rahman bin Abd Ghani. "Profesionalisme Guru Madrasah: Internalisasi Nilai Islam dalam Mengembangkan Akhlak Aktual Siswa." Jurnal Pendidikan Agama Islam Al-Thariqah 5.2 (2020): 79-96.

Tambak, Syahraini, M. Yusuf Ahmad, and Desi Sukenti. "Strengthening Emotional Intelligence in Developing the Madrasah Teachers' Professionalism (Penguatan Kecerdasan Emosional dalam Mengembangkan Profesionalisme Guru Madrasah)." Akademika 90.2 (2020).
Tambak, Syahraini, Amril Amril, and Desi Sukenti. "Islamic Teacher Development: Constructing Islamic Professional Teachers Based on The Khalifah Concept." Nazhruna: Jurnal Pendidikan Islam 4.1 (2021): 117135.

Wright, Thomas A., Emich, J. Kyle. "The Benefits of the 3-H Approach to Character Development." Organizational Dynamics (2019): 10. 